\title{
「情報管理」誌 投稿規定
}

独立行政法人 科学技術振興機構

「情報管理」誌編集委員会

当機構で編集·発行する月刊誌「情報管理」(Web 版，冊子体)への投稿はこの規定に従ってください。

\section{1. 編集方針}

\section{1 本誌の目的}

本誌は, 情報の整備·流通·活用の各段階に関わる方々が経験と知識や知恵を出し合い, 共有し, 話し合うた めのステージを提供し, 情報の生産から利用の「情報のサイクル」を活性化させることによって, 日本の情報科 学技術や情報リテラシ一の普及·向上を通じて科学技術振興の基盤整備に寄与することを目的としています。

\section{2 発行形態}

本誌は, Web 版「情報管理」(PDF および HTML)と，冊子体「情報管理」によって発行します。

\section{3 主題範囲と掲載記事の種類}

情報の整備·流通·活用に関する幅広い主題範囲を扱います。例としては,

学術情報流通, データベース, デジタルコンテンツ, 情報加工, 情報提供·利用, 情報技術,

規格·標準, 人材育成, 知的財産, 情報生活, 図書館·情報センター, 情報政策·制度 等 が挙げられます。

記事は, 総説·解説, 事例報告, 原著論文, 対談·座談会, 講演, 集会報告, 図書·ニュ一スの紹介, エッセ一・ オピニオンなど多岐にわたります。

\section{4 対象読者}

本誌は以下のような読者を対象としています。

*企業·大学·図書館などで, 情報を扱う業務に日ごろ従事している方々

* 研究·企画や営業などの専門業務にあたつて情報を発信·利用している方々

*オピニオンリーダー, 組織の意思決定に携わる方々

*情報に関心を持つ一般の方々

\section{2. 投稿にあたつて}

国の内外から広く，投稿原稿を受け付けています。

\section{1 原稿の種類}

総説·解説, 事例報告, 原著論文のいずれかに該当し，媒体を問わず他の出版物に発表されていない原稿を 受け付けます。原稿は原則として日本語とします。主題は, 1.3 に示した本誌の主題範囲を対象とします。

\section{2 査読と受理}

投稿原稿は編集委員会で査読し, 受理の可否を決定します。原稿の評価は, 内容の質と独創性, 読者にとつ て幅広い関心主題であるか否かに重点をおきます。また, 査読の結果をもとに著者に対し原稿内容の改善, な いし修正をお願いすることがあります。なお, 査読の後, 受理を決定した日をもって原稿の受理日とします。 


\section{3 著作権}

本誌に受理され，掲載された記事の著作権は科学技術振興機構に帰属します。記事の利用にあたつては 「『情報管理』誌著作権規定」に示した手続きに従ってください。

\section{3. 執筆要項}

別紙「情報管理』誌 原稿の書き方」に従って執筆してください。

\section{1 原稿の文字数と使用文字}

本文の文字数は, 1 記事 6,000 8,000 字(図表込みで刷り上がり 6 8 8゚ージ)を目安とします。

原則として常用漢字を用います。使用可能文字種は JIS 第二水準です。英数字は半角を用います。

\section{2 提出方法}

電子化したものを提出してください。本文は MS Word 形式とします。図表の形式については,「原稿の書き 方」の 4 に従ってください。

本文，写真，図，表は，それぞれ別ファイルとして用意し，原稿提出票とともにメール添付で下記編集 事務局宛てにお送りください。

厂102-8666 東京都千代田区四番町 5 番地 3

独立行政法人 科学技術振興機構「情報管理J編集事務局

Tel. 03 (5214) $8406 \quad$ Fax. 03 (5214) $8420 \quad$ E-mail: joho-kan@jst.go.jp

\section{4. 掲載にあたって}

受理が決定した原稿は, 以下のように取り扱います。

\section{1 著者校正}

初校時に 1 回のみ著者校正をお願いします。

\section{2 別刷りの提供}

掲載記事 1 件につき, 本誌 1 部と別刷り 10 部(表紙なし)を贈呈します。さらに別刷り(表紙あり, 有料)を希望 される場合は, 受理後に事務局からお尋ねしますので, 印刷手配前にお申し込みください。最低 50 部, 以降 10 部単位の印刷部数 $(60$ 部, 70 部, 80 部…としてください。

\section{3 原稿料}

掲載した原稿については, 当機構の規定に基づき, 所得税法に定める源泉徵収を行ったうえ, 原稿料をお支 払いします。 


\section{「情報管理」誌 原稿の書き方}

\section{1 記述項目}

以下の項目を順に記述してください。

(1) 標題(和文および英文)

(2) 著者名 (日本語およびロ一マ字)

(3) 著者の所属機関名および部署名(和文および英文)

(4) 著者の所属機関の住所(和文および英文), 電話番号, E-mail アドレス ※著者が複数の場合, (2)〜 (4)をそれぞれ記述してください。

（5）著者抄録 (和文および英文)：抄録は「科学技術情報流通技術基準 抄録作成 (SIST 01) 〈http://sti.jst.go.jp/sist/pdf/SIST01.pdf」を参考にして作成してください。なお，抄録の長さは，和文抄録 が 200 400 字, 英文抄録が 100 200 語程度です。抄録は和文, 英文両方を提出してください。

（6）著者付与キ一ワード(和文および英文) :和文キ一ワードに対応する英文キ一ワードを記載してください。 キーワードの数は 5 10 個までです。

(7) 本文

(8) 注記

（9）参考文献:参考文献としては，必ず本文に引用個所のある文献を挙げてください。

\section{2 章, 節などの見出し}

章, 節などの見出しには, ポイントシステムを使用してください。

例 第 1 章 $\rightarrow$ 1. はじめに

第 2 章, 第 1 節 $\quad \rightarrow 2.1$ 「情報管理 Web」とは

第 2 章, 第 1 節, 第 1 項 $\rightarrow$ 2.1.1 「情報管理」誌の電子化

項以下の細分 $\quad \rightarrow$ (2) XML 化

\section{3 文章と句読点}

文章は「である」調とし，簡潔で明確に表現してください。句読点は(, )および(。)を使用します。

\section{4 図-写真および表}

（1）図·写真および表には一連番号を付与し，簡潔なタイトルを付けてください。写真は図として扱います。

例「図 1 システム構成」「図 2 サーバ構成」‥,「表 1 システム仕様」「表 2 コンテンツ一覧」

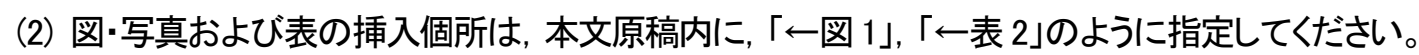

(3) 図·写真および表の刷り上がりの大きさは, 特に執筆者の指定がない限り当編集委員会に一任するものと します。

（4）画像の解像度は 300dpi 以上にしてください。

(5) 図および表デ一タは MS Word, Excel, PowerPoint で作成したものを提出してください。

(6) カラ一の図表は, 冊子体ではモノクロ印刷になることを想定して, 配色等にご注意ください。なお, Web 版お よび html 版ではそのままカラ一で表示されます。

\section{5 動画}

（1）各動画には一連番号を付与し，簡単なタイトルを付けてください。

（2）PDF および冊子用に, 特徵的な静止画像を添えてください。解像度は 300dpi 以上としてください。 


\section{6 参考文献と注記}

(1) 参考文献と注記は分けて記載してください。

（2）参考文献については, 本文の引用個所の右肩に引用ないし参照した順に, 1), 2), 3) $\cdots$ のように一連番号を 付けてください。

例 $\cdots$ については, 1995 年の調査 ${ }^{2)}$ があるが, $\cdots$

(3) 本文の後に, 参考文献の書誌事項を上記の番号順に記載します。上記のように, 参考文献闌にはは本文に引 用参考個所のある文献のみを記載してください。

（4）参考文献の記載は「科学技術情報流通技術基準 参照文献の書き方(SIST 02)」 〈http://sti.jst.go.jp/sist/pdf/SIST02-2007.pdf〉に従います。7に記載例を示します。

(5) 注記を使用する場合は, 本文の該当個所の右肩に, 注 1), 注 2) ․のように注番号を入れます。

(6) 注記の内容は, 本文の後, 参考文献の前に, 上記の番号順に記載してください。

\section{7 参考文献の記載例（SIST 02 参照文献の書き方 からの抜粋）}

(1) 雑誌記事を引用する場合

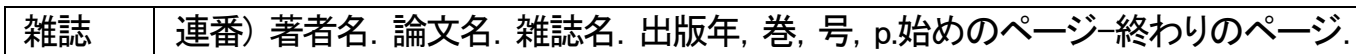

例 1 西潔, 石原和弘. 火山地域における震源計算についての提案. 火山. 2003, vol. 48, no. 5, p. $407-413$.

例 2 Pisciella, Paola; Pelino, Mario. FTIR spectroscopy investigation of the crystallisation process in an iron rich glass. Journal of the European Ceramic Society. 2005, vol. 25, no.11,p.1855-1861.

例 3 下山昌彦. セキュリティスキャナを用いた偽札の新しい検査手法の開発. CICSJ Bulletin. 2005, vol. 23, no. 3, p. 95-98. http://www.jstage.jst.go.jp/article/cicsj/23/3/23_95/_article/_char/ja/, (accessed 2006-03-07).

（電子ジャ一ナルの場合一入手先，(入手日付）.を加える。）

（2）図書を引用する場合

図書 $\quad$ 連番) 著者名. 書名. 版表示, 出版者, 出版年, 総ページ数 $\mathrm{p}$.

例 4 照明学会編. 照明ハンドブック. 第 2 版, オーム社, 2003, 573p.

例 5 Frenkel, D.; Smit, B. Understanding Molecular Simulation: From Algorithms to Applications. 2nd ed., Academic Press, 2002, 664p.

例 6 鵜飼保雄. “遺伝率の相対性”. 量的形質の遺伝解析. 医学出版, 2002, p. 109-110.

(図書の一部を参照した場合)

(3) Web ページ, Web サイトを引用する場合

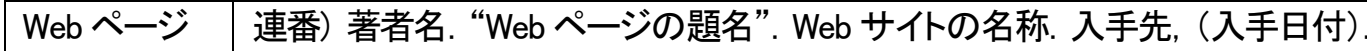

Web サイト

例 7 坂本和夫編. “パルスレーザーアブレ一ションにおけるドロップレットフリー薄膜の作製技術”

J-STORE. http://jstore.jst.go.jp/cgi-bin/techeye/detail.cgi?techeye_id=32, (accessed 2006-0623). 


\section{「情報管理「誌著作権規定}

（目的）

第 1 条 本規定は, 「情報管理」誌(Web 版, 冊子版を含む。以下, 本誌)に掲載される著作物に関する著 作権の取り扱いに関する基本事項を定める。

\section{（定義）}

第 2 条 本規定において，次の各号に掲げる用語は，当該各号に定める意義を有する。

(1) 本著作物 著作権法第 2 条第 1 項第 1 号に規定するものであって, 以下のいずれかに該当するもの をいう。

(1) 本誌に掲載される論文, 解説記事等(本編集委員会の依頼に基づくものを含む)

(2) 本誌に掲載される活動報告, エッセ一等(本編集委員会の依頼に基づくものを含む)

(3) その他前記(1)および(2)に類するものであって本編集委員会が指定するもの

(2) 本著作者 著作権法第 2 条第 1 項第 2 号に規定するものをいう。

(3) 本著作財産権 本著作物の著作財産権をいい, 著作権法第 21 条(複製権)，第 22 条(上演権及び演 奏権)，第 22 条の 2 (上映権)，第 23 条(公衆送信権等)，第 24 条(口述権)，第 25 条(展示権)，第 26 条(頒布権)，第 26 条の 2 (譲渡権)，第 26 条の 3 (貸与権), 第 27 条(翻訳権, 翻案権等)及び第 28 条(二次的著作物の利用に関する原著作者の権利)に定めるすべての権利を含む。

(4) 本著作者人格権 本著作物に関する著作者人格権をいい, 著作権法第 18 条(公表権), 第 19 条(氏 名表示権)及び第 20 条(同一性保持権)に定めるすべての権利をいう。

（著作権の帰属）

第 3 条 本著作財産権は, すべて独立行政法人科学技術振興機構(以下, 当機構)に帰属する。

2 本著作財産権は, 投稿後, 本編集委員会により本著作物の受理が決定された時点をもって 当機構に譲渡されたものとする。

3 特別な理由により前二項に定める取り扱いが不可能である場合, 本著作者は投稿を行う際 にその旨を当機構に対して書面で申し出るものとし, かかる場合の取り扱いについては, 本 編集委員会及び本著作者の協議によって定める。

4 前項に定める場合であっても, 本著作者は, 法令及び前項に定める特別な理由の許容する 範囲において, 当機構に対し, 本著作財産権について国内外で無償で独占的に利用する (複製, 公開, 送信, 頒布, 譲渡, 貸与, 翻訳, 翻案及び二次的著作物の利用を含む)権利を 許諾(有償無償を問わず, 当機構がサブライセンスを行う権利を含む)するものとする。

5 投稿された本著作物が本誌に掲載されないことが決定された場合, 当機構は, 本著作財産 権を本著作者に対して返還する。

（著作者人格権の不行使）

第 4 条 本著作者は, 当機構及び当機構が本著作物の利用を許諾した第三者に対し, 本著作者人格権 を行使しない。

2 前項の規定は, 当機構及び当機構が本著作物の利用を許諾した第三者が, 本著作物を原著 作物として二次的著作物を作成した場合においても適用される。

3 当機構は, 当機構が二次的著作物を創作する場合及び第三者に本著作物の利用を許諾する 場合には，本著作者にその旨を通知する。 
（著作者による著作物の利用）

第 5 条 本著作者は, 当該本著作者が創作した本著作物を利用する場合(第三者に利用を許諾する場合 を含む)，その利用目的等を当機構が別途定める事項を記載した書面により当機構に申請し， その許諾を得るものとする。

2 当機構は, 当該本著作物の利用が, 本誌の発行目的又は活動の趣旨に反しない限り, 前項 に定める本著作者からの申請を許諾する。

3 第 1 項の規定にかかわらず, 本著作者は, 次の各号に定める場合には, 当機構の許諾を得 ることなく本著作物を利用できるものとする。なお, 利用にあたっては出典(本誌誌名, 掲載 巻号, ページ, DOI等)を明記する。

（1）本著作者個人又は本著作者が所属する法人若しくは団体のWebサイトにおいて, 当該本著 作者が創作した本著作物を掲載する場合（機関リポジトリへの保存及び公開を含む）

(2) 著作権法第 30 条から第 50 条(著作権の制限)において許容された利用

（著作者による保証等）

第 6 条 本著作者は, 本著作物が, (1)第三者の権利を侵害していないこと, (2)本著作物が二重投稿では ないこと, 及び(3)本著作物が共同著作物である場合には, 当機構への投稿を行うにあたり, 当 該共同著作物の他の著作者全員の同意を取得していることを保証する。なお，本著作者は, 本 著作物において第三者の著作物を引用する場合には, 出典を明記する。

\section{(二重譲渡の禁止)}

第 7 条 本著作者は, 当機構以外の第三者に対し, 本著作物に係る一切の著作財産権の譲渡及びその 利用許諾(出版権の設定を含む)をしてはならない。

（紛争解決に関する協力）

第 8 条 本著作物に関する第三者からの権利侵害又は本著作物による第三者に対する権利侵害等, 本 著作物に関して紛争が発生した場合又は発生するおそれがある場合, 本著作者及び当機構は 相互に協力してこれに対処する。

(協議)

第 9 条 本規定に定めなき事項及び本規定の各条項の解釈に疑義が生じた場合, 本著作者及び当機構 は, 信義誠実の原則に従って協議し，これを解決するものとする。 